\title{
Factors influencing pulse consumption in Latin America
}

\author{
Pascal Leterme ${ }^{1 *}$ and L. Carmenza Muñoz ${ }^{2}$ \\ ${ }^{1}$ Universidad Nacional de Colombia, Departamento de Ciencia animal, A.A. 237 Palmira (Valle) Colombia \\ ${ }^{2}$ CIAT, Departamento de Biotecnología, A.A. 6713 Cali (Valle), Colombia
}

\begin{abstract}
In Latin America, pulse consumption ranges from $1 \mathrm{~kg} /$ capita per year (Argentina) to $25 \mathrm{~kg}$ / capita per year (Nicaragua). Common beans account for $87 \%$ of the total. The differences between countries, regions or groups of population within the same country can be explained by the following factors: (1) beans are very nutritious; (2) beans and maize are traditional foods and the habit of consuming them is deeply rooted in many people and communities; (3) the rural population eats more pulses than the urban population, due to geographical constraints that limit exchanges and favour consumption of locally produced foods; (4) income level, beans are still the poor man's meat; and (5) other factors, such as consumers' taste, the constraints on cooking beans, etc. The evolution of the consumption level in the future will depend on the urbanization of the population, access to processed foods and income level. Health issues would be an argument for maintaining or increasing the current consumption level.
\end{abstract}

Pulses: Beans: Consumption

\section{Introduction}

Pulses, together with cereals, have fed humans for millennia. Grains of chickpeas, peas, lentils or beans have been found in the traces of former civilizations, such as those of the Egyptians, Incas and Aztecs. These protein sources have been replaced progressively by animal products and their current contribution to protein supply is low, especially in industrialized countries.

In western Europe, pulse consumption does not exceed $3.5 \mathrm{~kg} / \mathrm{capita}$ per year (FAOSTAT, 2001), with great regional disparities. In other parts of the world, such as Latin America, India or Central Africa, pulse consumption is much higher, ranging from $10 \mathrm{~kg} / \mathrm{capita}$ per year in South America and India to more than $40 \mathrm{~kg} / \mathrm{capita}$ per year in Burundi (FAOSTAT, 2001).

Regular pulse consumption is now promoted by health organizations in Western countries because it helps reduce the risks for diseases such as cancer, diabetes or coronary heart disease (Geil \& Anderson, 1994; Leterme, 2002). In this regard, it is interesting to study the factors that explain the still high pulse consumption in other countries or continents. The present work discusses the factors that influence pulse consumption in Latin America.

\section{Pulse consumption in Latin America}

The average annual consumption of pulses per capita is detailed by country in Table 1 . The southern countries of the subcontinent are poor pulse consumers. Argentina, although an important bean producer, is the lowest consumer, partly due to the high level of meat consumption. Bolivia, Chile and Uruguay also present low rates of pulse intake. On the contrary, Brazil has, by far, the highest pulse intake per capita, essentially in the form of black beans. In this country, bean consumption is decreasing rapidly, mainly because of the young population and the fact that children eat fewer beans than adults. The consumption in the other countries ranges from 3.8 to $7.6 \mathrm{~kg} /$ capita per year. It is worth mentioning that in most of the Andean countries, beans account for less than $50 \%$ of the total pulse consumption.

Pulse consumption is higher in Central America and Mexico, but great differences are observed between the Central American countries: it ranges from $5 \mathrm{~kg} /$ capita per year in Costa Rica to more than $25 \mathrm{~kg} /$ capita per year in neighbouring Nicaragua. The latter has one of the highest bean consumption levels in the world.

However, the data provided by the Food and Agriculture Organization (FAO) may present some discrepancies with national statistical data. For example, the Costa Rican Ministry of Health, cited by Rodriguez-Castillo \& DumaniEchandi (2000) indicates a much higher level: $11.3 \mathrm{~kg} /$ capita per year $v$. the $5 \mathrm{~kg} / \mathrm{capita}$ per year announced by FAO. Some local consumption may not appear in the official surveys, which would mean that consumption might be higher than indicated by official statistics.

\footnotetext{
Abbreviations: FAO, Food and Agriculture Organization.

* Corresponding author: Dr Pascal Leterme, tel +57 227170 00, fax +57 227170 55, email johan@ uniweb.net.co
} 
Table 1. Pulse and bean consumption in Latin America in 1999 (FAOSTAT, 2001)

\begin{tabular}{lrr}
\hline & $\begin{array}{c}\text { Pulses } \\
\text { (kg/capita per year) }\end{array}$ & $\begin{array}{c}\text { Beans } \\
\text { (kg/capita per year) }\end{array}$ \\
\hline South America & & \\
Argentina & 1.1 & 0.0 \\
Bolivia & 2.7 & 0.4 \\
Brazil & $16 \cdot 1$ & $15 \cdot 7$ \\
Chile & 3.0 & 1.1 \\
Colombia & $6 \cdot 2$ & 3.7 \\
Ecuador & 3.8 & 1.4 \\
Paraguay & 7.6 & 7.1 \\
Peru & 7.6 & 2.7 \\
Uruguay & 3.1 & 1.3 \\
Venezuela & 5.5 & 4.1 \\
Total & 10.3 & 8.9 \\
Central America & & \\
Belize & 18.4 & 18.4 \\
Costa Rica & 5.0 & 4.7 \\
El Salvador & 11.9 & 11.9 \\
Guatemala & 10.8 & 7.7 \\
Honduras & 7.2 & 7.2 \\
Mexico & 12.6 & 10.9 \\
Nicaragua & 25.1 & 25.0 \\
Panama & 6.4 & 2.4 \\
Total & 12.3 & 10.7 \\
\hline
\end{tabular}

Factors explaining pulse consumption in Latin America

\section{Nutritional quality of pulses for humans}

Common beans (Phaseolus vulgaris) contain about $60 \%$ of carbohydrates, two-thirds of which in the form of starch, from 22 to $25 \%$ of proteins and a very low fat content (El-Tabey Shehata, 1992). They are also a valuable source of dietary fibre, calcium, iron and vitamins, such as folate. Compared to cereals, they are seen as a valuable source of protein that supplements well the low quality of cereal proteins. They are especially rich in lysine but somewhat deficient in methionine and tryptophan. A cereal: pulse ratio ranging from $1: 2$ to $1: 4$ on a dry matter basis, covers the human requirements for energy and essential amino acids (Food and Agriculture Organization, 1997; Briend, 1998). Surveys carried out in rural communities of the Andes and Central America confirm that beans are perceived as a food of great nutritional value, which people consider an important staple food (Tapia, 1985; Ruiz de Londoño et al. 2000).

\section{Tradition and culture}

Culture represents one of three predominant approaches used to explain food use and nutritional health, together with economy and psychology (McIntosh, 1996). According to Rozin (1998), the best predictor of the food preferences, habits and attitudes of any particular human would be information about his ethnic group and native cuisine, rather than any biological measure that one might imagine. Finally, McIntosh (1996) affirms that cuisine remains strongly rooted, even after language and other customs disappear during inclusion processes.

Beans, together with maize, were the staple food for the pre-Colombian civilizations, such as the Aztecs, Mayas and Incas, and remain so for the rural Indian communities of the Andes and Central America. Many authors have underlined the similarity in food habits between the native Indians and their ancestors (Tejada, 1979; Hurtado, 1984). Table 2 shows that food consumption in general, and pulse consumption in particular, have not changed very much for 35 years in rural communities of different Central American countries. Moreover, bean consumption is remarkably constant throughout the seasons, contrary to that of other foods, such as fruits, which are not available the whole year (Flores \& Flores, 1984). The maintenance of culture and food habits is favoured by the geographical isolation of many communities, due to the topography of the regions (mountains) and the strong willingness of these communities to maintain traditions.

The fondness of Hispanic populations for beans is reflected by the increase in bean consumption in the United States, which is only explained by the increase of the Hispanic population in this country (Lucier et al. 2000). Hispanic food habits and culture could even be adopted by other communities through restaurants or cultural mixing.

\section{Urbanization and geographical constraints}

Most of the South American countries are confronted by rural exodus and poorly planned development of urban zones. Rural exodus is caused by socio-economical factors,

Table 2. Average daily food consumption per person in rural areas of Guatemala, Panama and Honduras throughout time ( $\mathrm{g} /$ capita per day)

\begin{tabular}{|c|c|c|c|c|c|c|c|}
\hline & \multicolumn{3}{|c|}{ Guatemala } & \multicolumn{2}{|c|}{ Panama } & \multicolumn{2}{|c|}{ Honduras } \\
\hline & $1961^{*}$ & $1977 \dagger$ & $1987 \ddagger$ & $1952 \dagger$ & $1961^{*}$ & $1961^{*}$ & $1979+$ \\
\hline Dairy products (ml) & 10 & 93 & 21 & 82 & 47 & 136 & 210 \\
\hline Meat and eggs & 38 & 41 & 66 & 91 & 91 & 54 & 53 \\
\hline Pulses & 58 & 47 & 65 & 54 & 54 & 56 & 64 \\
\hline Vegetables and fruits & 86 & 112 & 189 & 126 & 78 & 175 & 108 \\
\hline Cereals & 494 & 685 & 530 & 289 & 189 & 367 & 308 \\
\hline Others & 53 & 162 & 78 & 137 & 123 & 69 & 58 \\
\hline
\end{tabular}

* Source: Flores (1961).

† Source: Flores \& Flores (1984).

¥ Source: Alarcón \& Adrino (1991). 
such as poverty, lack of employment and, in the case of Colombia, violence generated by the armed conflict. As a result, $80 \%$ of the population lives in urban areas. In Central America, $50 \%$ of the population still lives in the country (FAOSTAT, 2001).

Urbanization changes people's lives. They are out of home the whole day, must buy their food outside, etc. This modifies their food habits too: they have more choice, less time to cook, processed foods and meat are available and the pressure of the media is intense. Overall, incomes are also higher.

As a consequence, bean consumption is lower in urban areas. In Costa Rica, for example, the daily bean consumption reaches only $28 \mathrm{~g}$ beans/capita per day in town $v .43 \mathrm{~g}$ / capita per day in the rural communities (Rodriguez-Castillo \& Dumani-Echandi, 2000). However, when incomes are comparable between both groups, the difference is lower (Alarcón \& Adrino, 1991).

Many communities in the Andes and in Central America are also quite isolated in regions of difficult access. Exchanges are limited, which impedes diversification, and the composition of the diet depends mainly on local production. The latter depends on soil quality and climate. Temperature and precipitation vary according to the altitude: beans are produced roughly between 1500 and $3000 \mathrm{~m}$ above sea level. The limitation of exchanges partly explains why pulse consumption is higher in rural communities.

\section{Income}

Beans are also called the poor man's meat because they are a cheap source of protein. People with a low income usually turn towards bean or pulses when they can no longer afford meat. On the contrary, meat consumption increases with income. In case of extreme poverty, however, cereals are preferred to beans, due to their lower price. In South America, it is estimated that people in social strata with low income consume on average $20 \%$ more beans than those with the highest income (S. Beebe, personal communication).

\section{Consumers' preference}

The decision whether or not to consume a specific food depends on the factors described above, but also on everybody's own taste. However, even in this case, tradition still has a strong influence. For example, colour and grain size are the two main factors used to choose beans. In Brazil and Guatemala, people eat almost exclusively small black beans, in Nicaragua only small and medium-sized red beans, in Peru mainly cream-coloured or white beans, in Colombia mostly large red beans, etc. When asked why they prefer black or red beans, both Guatemalans and Nicaraguans say they are more tasty and nutritious than any other beans (Tapia, 1985; Diamant et al. 1989). On the contrary, when there is no tradition of bean consumption, colour is not an important criterion of choice. For example, in the city of Santa Cruz, Bolivia, where bean regional implantation is very recent, no particular

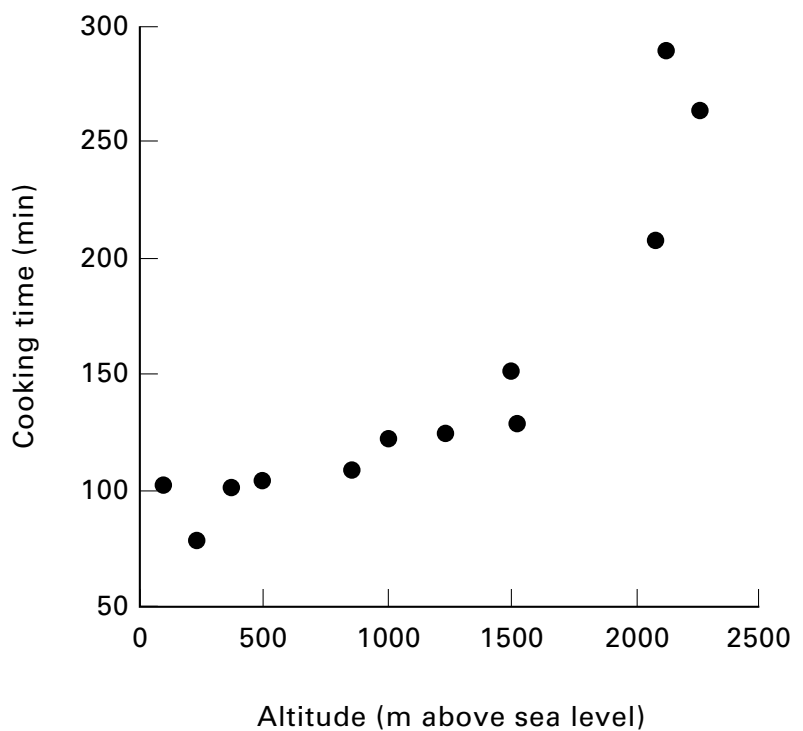

Fig. 1. Cooking time of beans as affected by altitude (after Diamant et al. 1989; Bressani \& Chon, 1996).

colour preference has been observed (Manrique Bargas, 1994).

Softness is generally the third factor influencing the consumer's choice. This is related to cooking time, which is a main concern when people do not have a pressure cooker, especially in the Andes and in Central America. Cooking time increases with the altitude: it requires more or less 100 minutes to cook beans at altitudes lower than $1000 \mathrm{~m}$ above sea level but nearly triple that at altitudes higher than $2500 \mathrm{~m}$ above sea level (Fig. 1) (Diamant et al. 1989; Bressani \& Chon, 1996), which is the case for cities such as Bogota, Quito or La Paz. When people refer to softness, they also want to avoid beans having been stored for a while and presenting the hard-to-cook defect. The latter has different causes and affects cooking time as well as the digestive processes (El-Tabey Shehata, 1992).

Finally, when asked why they were not keen to consume beans, $59 \%$ of the people of the city of Santa Cruz replied that they did not like them and $12 \%$ that it caused them problems of flatulence (Manrique Bargas, 1994). Women of the urban area of San José, Costa Rica, also claimed that beans cause intestinal problems, that they are too 'heavy' to be eaten at night and make people fat (Rodriguez-Castillo \& Dumani-Echandi, 2000).

\section{Discussion}

Bean consumption is deeply rooted in the habits of the populations of many countries in Latin America, with the exception of southern countries, such as Argentina. The difficulties of growing pulses in some regions explain the heterogeneous distribution only partly. For instance, Argentina is a big producer but a poor consumer. In the highlands, i.e. the Andes and part of Central America, the isolation of rural communities limits food exchange and favours local food consumption, including beans. This isolation also favours the maintenance of tradition 
and culture. The Indian communities are deeply attached to their traditions. Beans, together with maize, have been a staple food for centuries. Traditions and habits can also explain the great differences in consumption observed between neighbouring countries such as Costa Rica ( $5 \mathrm{~kg}$ / capita per year) and Nicaragua (25 kg/capita per year), or in bean colour preference.

However, the fast-developing urbanization occurring in South America might contribute to changing the trends. People change their life-style, have less time to cook, more choice of food, access to processed foods and are under the influence of the advertising media. A change like that observed in the southern countries of western Europe (Italy, Greece, Portugal, etc.) might be observed in South America in the future. In these countries, due to commercial pressure, people are abandoning the so-called Mediterranean diet, based on vegetables, pulses, fruits, grains, fish, olive oil and wine, and prefer sweet drinks, processed foods, fast food, etc. (Usher, 2001). This evolution will depend on economic development, but if a decline in pulse consumption is observed, it could hardly be re-established by health arguments, since people are often not concerned about the relationship between health and nutrition. For example, Rodriguez-Castillo \& Dumani-Echandi (2000) studied an educative campaign to promote bean consumption among the urban population of San José, Costa Rica. Although people were aware of the nutritive value of beans, they explain the decrease in bean consumption by their new life-style (less time to cook, women at work, etc.), the flatulence problem or their weight.

\section{Conclusions}

Pulses, in particular common beans, are still a staple food for the majority of the Latin American population. The stability of consumption throughout time can be explained by the weight of tradition, especially in isolated rural regions. Future evolution will depend on the evolution of the standard of living and of the urbanization of the population. An increase of income and of the urban population could reduce the global rate of pulse consumption markedly.

\section{References}

Alarcón J \& Adrino F (1991) Diferencias urbano-rurales en la ingesta de alimentos de familias pobres de Guatemala (Urban-rural differences in food intake in poor families of Guatemala). Archivos Latinoamericanos de Nutrición 16, 327-335.

Bressani R \& Chon C (1996) Effects of altitude above sea level on the cooking time and nutritional value of common beans. Plant Foods for Human Nutrition 49, 53-61.

Briend A (1998) La malnutrition de l'enfant (Child malnutrition). Danone Chair Monograph 6. Brussels: Institut Danone.

Diamant R, Watts B, Elias L \& Rios B (1989) Consumer utilization and acceptability of raw and cooked black beans
(Phaseolus vulgaris) in Guatemala. Ecology of Food and Nutrition 22, 183-195.

El-Tabey Shehata AM (1992) Hard-to-cook phenomenon in legumes. Food Reviews International 8, 191-221.

FAOSTAT (2001) FAOSTAT Database. Food supply: crop primary equivalent. http://apps.fao.org/page/collections?subset= nutrition.

Flores M (1961) Food patterns in Central America and Panama. In Tradition, Science and Practice in Dietetics. Proceedings of the Third International Congress of Dietetics, pp. 23-27. Bradford, UK, Byles and Sons Ltd.

Flores M \& Flores R (1984) Effects of dependence on seasonally available food. In Malnutrition: Determinants and consequences, pp. 207-219. New York: Alan Riss Edition.

Food and Agriculture Organization (1997) Agriculture, Food and Nutrition for Africa. Rome: FAO.

Geil PB \& Anderson JW (1994) Nutrition and health implications of dry beans: a review. Journal of the American College of Nutrition 13, 549-558.

Hurtado JJ (1984) Cultural determinants of food selection. In Malnutrition: Determinants and consequences, pp. 273-283. New York: Alan Riss Edition.

Leterme P (2002) Recommendations by health organizations for pulse consumption. British Journal of Nutrition 88, Suppl. 3, S239-S242.

Lucier G, Lin BH, Allshouse J \& Scott Kantor L (2000) Factors affecting dry bean consumption in the United States. Vegetables and Specialities 280, 26-34.

McIntosh WA (1996) Sociologies of Food and Nutrition. New York: Plenum Press.

Manrique Bargas R (1994) Estudio de consumo y mercado de frejol en el departamento de Santa Cruz (Bolivia) en 1992 (Study of bean consumption in the department of Santa Cruz (Bolivia) in 1992). Thesis, Universidad Autónoma 'Gabriel R. Moreno', Santa Cruz, Bolivia.

Rodriguez-Castillo L \& Dumani-Echandi M (2000) Campaña educativa con respecto al consumo de frijoles (Educative campaign on bean consumption). In Fourth Annual Workshop on Results of Research and Transfer Technology, pp. 29-36 [R Araya, editor]. San José, Costa Rica: University of Costa Rica.

Rozin P (1998) Towards a Psychology of Food Choice. Danone Chair Monograph 5. Brussels: Institut Danone.

Ruíz de Londoño N, García JA \& Pachico D (2000) Impacto de la adopción de frejol (Phaseolus vulgaris) en Santa Cruz, Bolivia (Impact of the adoption of beans (Phaseolus vulgaris) in Santa Cruz, Bolivia). Cali, Colombia: Centro Internacional de Agricultura Tropical.

Tapia H (1985) Criterios de selección y consumo de fríjol común en Nicaragua (Criterion of selection and intake of common beans in Nicaragua). In Proceedings of the Symposium: 'Necesidades actuales y futuras de alimentos en Centro América y Panamá' (Current and future requirements in food in Central America and Panama), pp. 42-47. Guatemala City, Republic of Guatemala.

Tejada C (1979) Nutrition and feeding practices of the Maya in Central America. In Aspects of the History of Medicine in Latin America, pp. 54-85 [J Bowers and E Purcell, editors]. New York: The Josiah Macy Jr Foundation.

Usher R (2001) The fat of the land: the inventors of the Mediterranean diet have become the most overweight people in Europe. Time Magazine 8 January, 32-33. 